\title{
Meta-Analysis of Intra-Industry FDI Spillovers: Updated Evidence*
}

\author{
Tomáš HAVRÁNEK - Czech National Bank and Charles University in Prague, Institute of Eco- \\ nomic Studies (tomas.havranek@ies-prague.org) - corresponding author \\ Zuzana IRŠOVÁ - Charles University in Prague, Institute of Economic Studies \\ (zuzana.irsova@ies-prague.org)
}

\begin{abstract}
Using 67 published and unpublished studies, we conduct a meta-analysis of the literature on intra-industry productivity spillovers from foreign direct investment. The combined significance test of individual t-statistics is inconclusive, but it is apparent that papers published in leading journals tend to report insignificant results. Meta-regression analysis confirms that cross-sectional and industry-level studies are likely to find relatively strong spillover effects and that the choice of the proxy for foreign presence is important. The pattern, however, seems to weaken over time. Evidence for publication selection bias was detected employing the funnel asymmetry test, and the spillover effect corrected for publication bias is not significantly different from zero.
\end{abstract}

\section{Introduction}

Governments all over the world pay fortunes, either in cash or as tax holidays, to attract inward foreign direct investment (FDI) under their jurisdiction. There are many reasons why governments attempt to lure multinational companies (MNCs), but the principal one resides in their expectations of positive productivity externalities spilling over from MNCs to domestic firms (Blomström and Kokko, 2003). A substantial body of empirical literature on productivity spillovers has been published since the 1970s, and many narrative literature reviews have been conducted (see, inter alia, Pack and Saggi, 1997). The first quantitative survey, commonly called a meta-analysis, was conducted by Görg and Strobl (2001), followed by Meyer and Sinani (2005) and Wooster and Diebel (2006).

Meta-analysis is a relatively new method in economics; it has been employed only since the 1980s, and the meta-regression approach, which is the main focus of this paper, was developed by Stanley and Jarrell (1989). The recent economic research by means of meta-analysis covers for instance Gallet (2007) trying to uncover the extent to which study characteristics influence the estimates of tuition and income elasticities, $\mathrm{Li}$ et al. (2007) investigating systematic variation across the results of studies on the environmental Kuznets curve, Fidrmuc and Korhonen (2006) studying the business cycle correlation between the euro area and the Central and Eastern European economies, and Havránek (2010) investigating the effect of currency unions on intra-union trade.

\footnotetext{
* We gratefully acknowledge financial support from the IES Research Institutional Framework 2005-2010 (MSMT 0021620841) and Grant Agency of Charles University (GAUK 768/10 A-EK). We thank Vladimír Benáček, Tomáš Cahlík, Pekka Ilmakunnas, Ladislav Krištoufek, participants of the AAEM seminar at Charles University in Prague, and two anonymous referees of this journal for valuable comments. All remaining errors are our own. The views expressed in this article are not necessarily those of the Czech National Bank.
} 
A meta-analyst rigorously combines the outcomes of several papers that study the same phenomenon. A meta-regression analyst, to be specific, collects a number of statistics from the literature - e.g., correlation coefficients or $t$ statistics of estimates of the effect in question - and regresses them on several proxies of study design to investigate systematic dependencies (for a good introduction to the meta-regression technique, see Stanley, 2001). Concerning the meta-analyses of the spillover literature, Görg and Strobl (2001) apply ordinary least squares (OLS) meta-regression, Meyer and Sinani (2005) employ panel data methods, and Wooster and Diebel (2006) perform logistic meta-regression. We combine all the three methods and include also robust estimations to check the sensitivity of our results. The sample of literature used in this meta-analysis, containing 67 original empirical studies, is also much broader than in the previous analyses. What is more, we apply the modern methodology of correcting for publication bias (Doucouliagos and Stanley, 2009; Doucouliagos and Laroche, 2009) to the spillover literature.

The present paper is structured as follows. Section 2 lists channels of transfers of intra-industry (or horizontal) spillovers from MNCs to domestic firms, discusses the determinants of spillovers, and describes the standard design of empirical studies on horizontal spillovers. Section 3 discusses in detail the literature selection procedure we employed and describes the properties of the resulting data set. Section 4 investigates the combined significance of the collected $t$ statistics. In Section 5 the meta-regression analysis is performed. Section 6 tests for the presence of publication bias in the spillover literature. Section 7 concludes.

\section{Horizontal Spillovers from FDI}

The history of the literature on intra-industry productivity spillovers ${ }^{1}$ dates from 1960, covering the work of MacDougall (1960), Corden (1974), and Caves (1974), who analyzed the welfare effects of FDI, its impact on optimal tariff policy, industrial level, and international trade openness. A deeper specification is provided in Blomström and Kokko (1996), embodied in the three main channels of technology transfer:

\section{Competition effect}

The entry of foreign enterprises contributes to development on the industrial, technological, and managerial level and to export dynamics through the creation of a competitive environment. Nevertheless, multinational companies may evoke crowding-out effects, generating harmful externalities for domestic firms. MNCs can acquire significant market shares, reducing the opportunities of domestic firms to exploit returns to scale (Aitken and Harrison, 1999), or drain scarce resources. Such detrimental effects of FDI are highlighted by several researchers (for instance, Haddad and Harrison, 1993, who, in fact, present evidence of negative horizontal spillovers).

\section{Demonstration effect}

Realization of the demonstration effect stems from the differences in technology level between foreign investors and host-country firms. MNCs enter the host-country market and establish affiliates which possess superior technology compared

\footnotetext{
${ }^{1}$ Examination of vertical spillovers, following the seminal work of Javorcik (2004), has become popular in the recent literature. This article, however, focuses on horizontal spillovers. Other FDI externalities than productivity spillovers have been discussed as well, specifically the market access spillovers (e.g., Blomström and Kokko, 2003) and financing spillovers (Geršl, 2008), but there are only a few empirical studies estimating those.
} 
to the local companies. Locals observe and imitate these affiliates in the same industry, thus becoming more productive. In some cases, only direct contact with new technologies can overcome conservative attitudes toward the implementation of up-to-date technologies (Blomström and Kokko, 1996).

\section{Labor turnover}

Host country citizens employed by the foreign investor might benefit from contact with advanced technologies and production methods. Based on the transfer of human capital, knowledge, and skills to the host country labor force, this labor exchange phenomenon can enhance the competitiveness of domestic firms. MNCs train local labor force since this is still cheaper than importing skilled labor from their home country, even though, in most cases, they cannot prevent labor turnover (Görg and Greenaway, 2004).

Researchers have recently been turning their attention toward the question of spillover heterogeneity. It has been shown that the existence, polarity, and magnitude of FDI spillovers depends on various factors related especially to MNCs, domestic firms, and regional characteristics (for a comprehensive survey of spillover determinants, see Crespo and Fontoura, 2007).

The most frequently pronounced determinant is the absorptive capacity of domestic firms - their ability to adopt new technologies from MNCs. The technological gap is often employed to approximate this determinant: the importance of FDI spillovers is maximized if the technological gap is moderate - not too high but also not too low (Kokko, 1994). As another proxy, R\&D expenditures are also used (Griffith et al., 2003). At the macro level, many authors associate the absorptive capacity with the host country's development (see Xu, 2000, or Lipsey and Sjöholm, 2004 in the context of the labor channel: developing countries may benefit less from labor turnover since it is difficult for domestic firms to offer wages competitive with MNCs), human capital (more advanced technology is connected with a higher proportion of skilled labor - Blomström et al., 1994; Kokko and Blomström, 1995) or a developed financial system (which reduces the investment risk of domestic firms willing to adopt new technologies - Hermes and Lensink, 2003).

The theory behind regional effects, another major determinant, suggests that FDI spillovers decrease with increasing geographical distance between domestic firms and MNCs (Audretsch, 1998), since the three channels described above are limited in space (Girma, 2003; Torlak, 2004). Additionally, there are various determinants related to domestic firms' characteristics. With regard to firms' export capacity, FDI spillovers may be higher for non-exporting domestic firms since the exporting ones already face sufficient competition pressures (Blomström and Sjöholm, 1999), the domestic market is less relevant for them and they are more experienced with foreign competition (Barrios and Strobl, 2002; Schoors and Tol, 2002); therefore, the entry of MNCs would not cause high competition effects for such companies. Another factor is firm size; small firms unable to profit from returns to scale may be less able to compete with MNCs. Concerning different types of firms, private or state ownership, for example, may influence firms' absorptive capacity (see Sinani and Meyer, 2004).

The other important factors include trade policy environment: with inward-oriented policy, for example, MNCs are likely to use technologies unknown to do- 
mestic firms (Kokko et al., 2001). Lee and Mansfield (1996) suggest that the level of protection of intellectual property rights increases the probability that MNCs will use more advanced technology, augmenting the magnitude of spillovers. Fosfuri et al. (2001) find evidence for the importance of the type of training received by workers at MNCs and the existence of restrictions on labor mobility. According to Wang and Blomström (1992), MNCs facing strong competition would use more advanced technology; on the other hand, Fosfuri et al. (2001) argue that this would lead MNCs to protect their know-how more carefully.

Many of the firm-level determinants have been tested in the spillover literature and found significant for the magnitude and polarity of productivity spillovers. While in this article we search for methodological spillover determinants (i.e., how the methodology chosen by the researcher can systematically influence the reported results), it is important to keep in mind that there might exist some real heterogeneity in the spillover literature.

Since it is not possible to measure the three channels of technology transfer directly, empirical studies on horizontal productivity spillovers are usually performed in the following way: researchers collect data on firms' productivity or output (on either the firm or industry level) and regress it on a measure of foreign presence in the firms' industries, controlling also for additional variables (capital/output ratio, industry competition, etc.). If the estimate of the parameter for foreign presence is found to be positive and significant, the authors conclude that there is some statistical evidence for the existence of intra-industry spillovers.

\section{Sample of Literature}

In the present paper, 97 results from 67 different studies are used, which is a significant increase compared to Görg and Strobl (2001), who used a sample of 21 studies, or Meyer and Sinani (2005) and Wooster and Diebel (2006), who had at their disposal 41 and 32 studies, respectively. We tried to include all relevant papers listed in the previous meta-analyses; additional searches were performed in the EconLit, RePEc, and Google Scholar databases using combinations of the keywords "foreign direct investment," "productivity spillovers," and "technology transfer."

We follow the approach of Görg and Strobl (2001) in the selection process, i.e., only those studies which do not diverge significantly from the standard methodology as described in Section 2 are included, and only English-written papers are considered. No pre-selection for quality was employed. In first place, we do not use results for inter-industry (or vertical), innovation, market access, and financing spillovers. These categories are qualitatively relative, but the tested specifications are, in our opinion, too dissimilar to be pooled together in the framework of a meta-analysis, and it would be much more appropriate to analyze such streams of literature separately. The more distant are the models used, the more heterogeneous the sample becomes and the less reliable are the results drawn from it.

Excluding inter-industry, innovation, market access, and financing spillovers, there is still a substantial body of empirical literature dealing with horizontal productivity spillovers. Many papers present multiple models, and thus multiple results. As a rule, we tried to choose the one that was considered the best by the researchers themselves. If the preferred model was not suitable for the analysis, i.e., it diverged too much from the standard methodology, the model with the highest $R$-squared was 
selected. There are also studies that examine different countries with the same methodology, or one country with different specifications which are, nevertheless, consistent with the mainstream approach (such estimates are called "conceptually independent" in the meta-analysis literature). For example, Konings (2000) studies spillovers in Bulgaria, Poland, and Romania separately, thus three observations were included from his paper. Liu (2008) first presents a purely firm-level model but subsequently adds industry dummies, thus we obtain two observations from this paper, etc. On the other hand, Sadik and Bolbol (2001) apply not industry- or firm-, but country-level aggregation, and Zhu and Tan (2000) use a city-level data set, therefore we do not include these papers - although Wooster and Diebel (2006) do use them. Rattsoe and Stokke (2003) employ two proxies for foreign presence at the same time: the shares of trade in GDP and FDI in overall investment, neither of them belonging to the standard measures in the spillover literature - thus this paper is also excluded from the meta-analysis. In the meta-regression framework, it is difficult to model idiosyncratic research choices.

We realize that the selection process is the most vulnerable part of the present work, but the final sample is broad and represents the work of researchers from dozens of countries and evidence from many economies around the world. Both journal articles and working papers were used. The list of studies and some of their characteristics can be found in Table 7 in Appendix $A .^{2}$

The first aspect of the study design that we include in the meta-analysis is the status of the country for which the data are used. From the whole sample of 97 observations, 41 models use data for developing countries, 34 use data for transition countries, and 22 use data for advanced economies. Countries are distributed into groups according to the European Economic Association (transition countries list) and the World Bank (developing economies list) as of 2008. The second aspect is the (non)existence of a time dimension in the data. Thirty-two models use cross-sectional data; the remaining 65 models rely on panel-data techniques. The third aspect is the definition of MNCs' presence. Thirty-two specifications define foreign presence in the industry as foreign firms' share in employment, 25 use assets, 21 output (or value added), and 19 share in sales. The fourth aspect is the level of aggregation. Forty models use purely firm-level data, whereas 35 also include industry dummies and 22 aggregate data on the level of industries. The fifth aspect is the definition of the response variable. Thirty-nine specifications use output growth, 54 models apply labor (or total factor) productivity level or log-level, and the rest employ other measures (for details of the different measures, see Görg and Strobl, 2001). Exact definitions of all variables and their summary statistics can be found in Table 8 in Appendix A.

\section{Combined Significance}

Once we have collected a broad sample of empirical studies on intra-industry spillovers, the most natural question appears to be: can we somehow decide whether or not there is any general evidence for the existence of the spillover effect? The crucial results of every empirical study of productivity spillovers are the significance, polarity, and magnitude of the estimate of the regression parameter which corresponds to

${ }^{2}$ Tables 7-14 in Appendixes A-C can be found on the web page of this journal: http://journal.fsv.cuni.cz/. 
the variable used as a proxy for foreign presence in the industry. Since each research er can use different units, it is not appropriate to take the magnitude of estimates as the representative variable. The $t$ statistic, on the other hand, is a dimensionless variable which is widely employed for the purposes of meta-analysis (it is also used by all three existing meta-analyses of the spillover literature: Görg and Strobl, 2001; Meyer and Sinani, 2005; Wooster and Diebel, 2006).

The first possible way of evaluating combined significance is to employ the so-called "vote-counting method" (see, inter alia, Hunter and Schmidt, 1990). Following this approach, one would count the median value of the $t$ statistics in the sample; let us denote it $T_{M}$. If the median value was significant, this could be taken as evidence for the existence of the phenomenon in question. This method has been criticized by Djankov and Murrell (2002), for example. Instead of the vote-counting method, they examine the following statistics:

$$
T=\frac{\sum_{k=1}^{K} t_{k}}{\sqrt{K}}
$$

where $K$ denotes the number of models included in the meta-analysis (i.e., $K=97$ in our case) and $t_{k}$ is the $t$ statistic taken from the $k$-th model. Provided that all studies are independent and have a sufficiently large number of degrees of freedom, $T$ is normally distributed and combined significance can be easily tested. Note that, from this point of view, the vote-counting method substantially undervalues the "real" effect. Indeed, many meta-analysts (e.g., Hedges and Olkin, 1985) consider it to be obsolete. Still, it is widely used, especially in narrative literature reviews.

Djankov and Murrell (2002) also propose another modification of (1):

$$
T_{W}=\frac{\sum_{k=1}^{K} w_{k} t_{k}}{\sqrt{\sum_{k=1}^{K} w_{k}^{2}}}
$$

where $w_{k}$ are the weights assigned to the $k$-th model, $T_{W}$ being normally distributed. Both (1) and (2) are used in meta-analyses of the spillover literature. Meyer and Sinani (2005) assign higher weights to models that employ "sophisticated econometric methods". Wooster and Diebel (2006) use the inverse of the number of models taken from a particular paper (for example, if three models are taken from the paper, each has a weight of 1/3). We define a combined weight which accounts for (i) the number of models taken from a particular paper as in Wooster and Diebel (2006), and (ii) the "quality" of the paper. Quality is proxied by the level of publication, i.e., working papers have the lowest weight $(w=0.25)$, articles published in lesser journals have moderate weight $(w=0.5)$, and articles published in the top 60 economics journals according to the list by Kalaitzidakis et al. (2003) have the full weight $(w=1)$. It would be possible to take more complicated weights, e.g., some distribution of impact factors, but then there would be a problem with weights for working papers. Nevertheless, even such simple weights have a significant impact on the results, as can be seen from Table 1 .

Table 1 shows the combined significance of the spillover effect in different groups of the sample. Both the normally distributed statistics $T(1)$ and $T_{W}(2)$, and 
Table 1 Aggregated $t$ Statistics

\begin{tabular}{lcc|ccc|ccc}
\hline \multirow{2}{*}{ Variable } & \# of & Without & \multicolumn{3}{|c|}{ All studies } & \multicolumn{3}{c}{ Without outliers } \\
\cline { 4 - 9 } & obser. & outliers & $T$ & $T_{W}$ & $T_{M}$ & $T$ & $T_{W}$ & $T_{M}$ \\
\hline all & 97 & 87 & 15.5 & 10.1 & 0.4 & 4.41 & 3.99 & 0.3 \\
developing & 41 & 38 & 6.95 & 2.11 & 0.9 & 4.54 & 3.27 & 0.811 \\
transition & 34 & 31 & 9.12 & 8.13 & -0.00423 & -0.569 & -0.645 & -0.193 \\
advanced & 22 & 18 & 11.8 & 13.6 & 1.4 & 3.85 & 4.4 & 0.85 \\
cs & 32 & 28 & 21.3 & 16.4 & 2.77 & 10.4 & 9.28 & 2.41 \\
panel & 65 & 59 & 4.02 & -1.05 & 0.000265 & -1.8 & -3.098 & 0.000185 \\
empl & 32 & 28 & 13.2 & 11.9 & 1.85 & 6.907 & 7.9 & 1.4 \\
sales & 19 & 16 & 3.10 & -3.15 & -0.323 & -1.03 & -1.98 & -0.326 \\
assets & 25 & 23 & 6.81 & 3.55 & 0.0507 & -0.417 & -2.96 & 0.037 \\
output & 21 & 20 & 6.64 & 4.17 & 0.9 & 2.4 & 2.74 & 0.7 \\
firm & 40 & 35 & 6.03 & 0.491 & 0.312 & 0.214 & -1.28 & 0.3 \\
industry & 22 & 21 & 10.8 & 9.57 & 2.41 & 9.22 & 8.17 & 2.4 \\
secdum & 35 & 31 & 10.8 & 10.4 & 0.000265 & -0.42 & 0.477 & $2.28 \cdot 10^{-6}$ \\
growth & 39 & 33 & 12.5 & 6.29 & 0.4 & 2.46 & -0.358 & 0.324 \\
prod & 58 & 54 & 9.82 & 7.97 & 0.531 & 3.68 & 4.92 & 0.282 \\
old & 46 & 42 & 11.3 & 6.068 & 1.0 & 4.77 & 4.066 & 0.75 \\
new & 51 & 45 & 10.7 & 8.41 & 0.324 & 1.53 & 1.48 & 0.051 \\
journal & 32 & 28 & 17.4 & 16.2 & 1.42 & 6.19 & 5.64 & 0.811 \\
wp & 42 & 39 & 3.69 & 6.76 & 0.0258 & 2.086 & 4.73 & 0.000957 \\
topjournal & 23 & 20 & 6.35 & 1.43 & 0.99 & -1.029 & 0.499 & 0.445 \\
\hline & & & & & & & & \\
\hline
\end{tabular}

Notes: all stands for dataset including all available data; developing restricts overall dataset to developing countries only; transition to transitional countries, and advanced to advanced countries; cs is a subsample of studies using cross-sectional data and panel using panel data; empl is a subsample for studies measuring MNC presence in employment; sales in sales; assets in assets; and output in output; firm is a sample restricted to studies on firm-level; industry for industry-level; secdum if industry dummies are used; growth is a dummy variable equal to 1 if response variable is output growth and prod if labor productivity; new stands for studies published since 2003; old otherwise; journal restricts the sample to articles published in other journals than topjournals; wp stands for working papers; topjournal denotes articles published in the leading 60 economics journals.

$T_{M}$ is median $t$ statistic; $T$ and $T_{W}$ are based on (1) and (2), respectively.

the median value $T_{M}$ are reported. The values of $t_{k}$ from our sample vary significantly, from a low of -11.58 to a peak of 27.7. Because such excessive values have a rather dramatic effect on the combined significance, we also report $T, T_{W}$, and $T_{M}$ for a narrower sample without these outliers. More specifically, we employ the restriction $\left|t_{k}\right| \leq 8$, thus the narrower sample contains 87 observations. From these six measures of combined significance, we would prefer $T_{W}$ without outliers. It is evident at first sight that the weighted value $\left(T_{W}\right)$ is in most cases below the simple measure $T$, indicating that better-quality papers may report lower $t$ statistics, or that discounting the weights for multiple models taken from one paper has a powerful effect. Nevertheless, for the pooled sample both $T$ and $T_{W}$ are highly significant, even with the exclusion of outliers. $T_{M}$, on the other hand, is not significant. To conclude, the spillover effect is, in general, not significant according to the vote-counting method, but it is significant applying the Djankov and Murrell (2002) methodology.

There are two groups in the sample for which the spillover effect is significant independently of the methodology in use or spillover exclusion, namely, studies 
using cross-sectional data and studies with industry-level aggregation. Specifications that measure MNCs' presence as a share of employment are together not significant only when the combined $t$ statistic is measured by $T_{M}$ without outliers. On the other hand, for firm-level specifications, panel data models, studies using sales as a measure of foreign presence, and papers published in the top 60 world economics journals, combined $t$ statistics are positively significant only if they are measured simply as $T$ and outliers are included; the remaining five measures are insignificant or even negatively significant. Based on this finding, one could argue that there might be a tendency in the most prestigious journals to publish rather skeptical empirical studies on productivity spillovers, or - perhaps more probably - that papers of high quality might be more likely to find no or even negative spillover effects. However, at first sight, it seems that the effect of quality on the results is not linear, since studies published in lesser journals are more likely to find positive spillovers than studies published only as working papers. But recent working papers can still be published in a journal, be they top ones or not, thus the "mixed" results for working papers do not contradict our main argument. Based on several sensitivity checks, we would argue that the trend among the most respected journals is obvious and that minor changes to the definitions of the top journals would not change the conclusion.

It is also worth noting that for transition countries excluding outliers all three combined $t$ statistics are insignificant and even negative. This may be surprising, since transition countries are usually considered to be likely to benefit highly from FDI, as in their case the technology gap between domestic firms and MNCs is moderate (see, e.g., Blomström and Kokko, 2003). Furthermore, it seems that newer studies (those published after 2002, dividing the sample approximately into two halves) might be more likely to report insignificant results, although the effect of study age does not appear to be very strong.

\section{Meta-Regression Analysis}

We have already seen that various aspects of study design are likely to influence the results, namely, the $t$ statistic for the estimate of the coefficient that represents the measure of foreign presence in the industry. In this section, we would like to investigate this pattern more thoroughly, using a different approach known as meta-regression analysis. As a benchmark case, we follow Görg and Strobl (2001), who run an OLS regression:

$$
Y_{k}=\alpha+\sum_{l=1}^{L} \beta_{l} X_{k l}+\varepsilon_{k}, \quad k=1,2, \ldots, K
$$

where the meta-response variable $Y_{k}$ is the $t$ statistic from the $k$-th specification and meta-explanatory variables $X_{k l}$ reflect different aspects of study design according to the five main features from Section 3, i.e., those that can be chosen by the researchers ex ante. ${ }^{3}$ For this reason, we do not include a dummy for the level of publication. Because in the absence of publication bias there should be a significant and positive relation between the number of degrees of freedom in the particular model and its reported (absolute) $t$ statistic value, the logarithm of degrees of freedom provides an ad-

\footnotetext{
${ }^{3}$ Baseline case: data are firm-level, panel, and for a developed country, the response variable is specified in productivity level, log-level, or "other," and foreign presence is measured in sales.
} 
Table 2 Summary of Meta-Regressions, All Studies

\begin{tabular}{|c|c|c|c|c|c|}
\hline $\begin{array}{l}\text { Response variable: } t \text { statistic; } \\
\text { dummy }=1 \text { if positive (probit) }\end{array}$ & OLS & IRLS & Median reg. & RE & Probit \\
\hline \multirow[t]{2}{*}{ Logarithm of degrees of freedom } & 0.0969 & 0.137 & 0.100 & 0.0828 & 0.0666 \\
\hline & $(0.69)$ & $(1.06)$ & $(0.78)$ & $(0.60)$ & $(0.79)$ \\
\hline \multirow[t]{2}{*}{ Average year of study period } & -0.0119 & -0.0216 & -0.0239 & -0.00560 & -0.0195 \\
\hline & $(-0.40)$ & $(-0.62)$ & $(-0.71)$ & $(-0.18)$ & $(-0.54)$ \\
\hline \multirow{2}{*}{$\begin{array}{l}\text { Dummy = } 1 \text { if data are for developing } \\
\text { country }\end{array}$} & -0.124 & 0.0353 & -0.0411 & -0.247 & 0.264 \\
\hline & $(-0.23)$ & $(0.05)$ & $(-0.07)$ & $(-0.47)$ & $(0.53)$ \\
\hline \multirow{2}{*}{$\begin{array}{l}\text { Dummy = } 1 \text { if data are for transition } \\
\text { country }\end{array}$} & 0.805 & 0.833 & 1.068 & 0.727 & 0.635 \\
\hline & $(0.99)$ & $(1.03)$ & $(1.37)$ & $(0.89)$ & $(1.08)$ \\
\hline \multirow[t]{2}{*}{ Dummy = 1 if data are cross-section } & $2.023^{* \star \star}$ & $1.876^{\star \star \star}$ & $2.363^{* \star \star}$ & $1.993^{\star \star \star}$ & $1.123^{* \star}$ \\
\hline & $(3.16)$ & $(2.91)$ & $(3.70)$ & $(3.10)$ & $(2.46)$ \\
\hline \multirow{2}{*}{$\begin{array}{l}\text { Dummy }=1 \text { if response variable is } \\
\text { output growth }\end{array}$} & $0.973^{*}$ & 0.880 & 0.839 & 0.756 & 0.162 \\
\hline & $(1.91)$ & $(1.64)$ & $(1.57)$ & $(1.47)$ & $(0.46)$ \\
\hline \multirow[t]{2}{*}{ Dummy = 1 if data are industry-level } & $1.851^{* \star *}$ & $1.884^{* \star}$ & 0.770 & $1.787^{\star \star \star}$ & $1.602^{\star *}$ \\
\hline & $(2.85)$ & $(2.37)$ & $(1.03)$ & $(2.74)$ & $(2.27)$ \\
\hline \multirow[t]{2}{*}{ Dummy = 1 if industry dummies used } & 0.237 & 0.344 & 0.468 & 0.353 & 0.297 \\
\hline & $(0.38)$ & $(0.61)$ & $(0.84)$ & $(0.54)$ & $(0.86)$ \\
\hline \multirow{2}{*}{$\begin{array}{l}\text { Dummy = } 1 \text { if MNC presence } \\
\text { measured in employment }\end{array}$} & $1.510^{* *}$ & $1.436^{*}$ & $2.216^{\star \star \star}$ & $1.808^{* *}$ & $1.411^{\star \star}$ \\
\hline & $(2.23)$ & (1.77) & $(2.94)$ & $(2.42)$ & $(2.45)$ \\
\hline \multirow{2}{*}{$\begin{array}{l}\text { Dummy = } 1 \text { if } \mathrm{MNC} \text { presence } \\
\text { measured in assets }\end{array}$} & 0.329 & 0.553 & 1.036 & 0.577 & 0.695 \\
\hline & $(0.47)$ & $(0.73)$ & $(1.42)$ & $(0.74)$ & $(1.42)$ \\
\hline \multirow{2}{*}{$\begin{array}{l}\text { Dummy = } 1 \text { if MNC presence } \\
\text { measured in output }\end{array}$} & 1.159 & 1.148 & $1.856^{* \star}$ & 1.505 & 0.841 \\
\hline & $(1.39)$ & $(1.40)$ & $(2.25)$ & $(1.60)$ & $(1.62)$ \\
\hline \multirow[t]{2}{*}{ Constant } & 20.85 & 39.86 & 44.44 & 8.379 & 37.03 \\
\hline & $(0.35)$ & $(0.57)$ & $(0.66)$ & $(0.13)$ & $(0.51)$ \\
\hline Observations & 87 & 97 & 97 & 87 & 97 \\
\hline $\begin{array}{l}R^{2} \text { (pseudo } R^{2} \text { for median reg. and } \\
\text { probit) }\end{array}$ & 0.342 & 0.258 & 0.128 & 0.335 & 0.238 \\
\hline
\end{tabular}

Note: OLS and RE computed excluding outliers; heteroskedasticity robust (Huber-White sandwich est.) $t$ statistics in parenthesis.

${ }^{*} p<0.10,{ }^{* *} p<0.05,{ }^{* * *} p<0.01$.

ditional meta-explanatory variable. Another aspect we would like to control for is the time period for which the study was conducted, thus we include the average year of study period as a meta-explanatory variable. The final model consists of 11 meta-explanatory variables for 97 observations, which gives us far more degrees of freedom than Görg and Strobl (2001) have (25 observations for 9 regressors).

Descriptions of all the variables can be found in Table 8 in Appendix A. First, we examine the relationships between the meta-explanatory variables. The table of correlation coefficients (Table 10) is included in Appendix $C$ - the highest absolute value of all the correlation coefficients, 0.63 , does not seem to indicate multicollinearity. The condition number is high, but if we exclude the average year of study period it declines to 16 . In the regression model, the exclusion of this variable does not change the estimated signs or the significances of the estimates, thus we mostly work with the complete number of meta-explanatory variables. Further discussion of multicollinearity can be found in Appendix B.

All the regressions were conducted in Stata 10 and the most important results employing different estimators are summarized in Table 2. Detailed results of the stand- 
ard meta-regression using OLS are reported in Table 11 in Appendix C. We found it necessary to exclude the most obscure observations - with $\left|t_{k}\right|>8$. There are three main reasons for such selection. Firstly, observations with such a high absolute $t$ statistic also have the largest Cook's distances for specification 1 of Table 11 and their predicted residuals are high. Secondly, there is a large gap between the observation with the absolute $t$ statistic of 5.9 and the next higher one of 8.4 . Thirdly, this is a similar cut-off level to that used by Görg and Strobl (2001). Nevertheless, we report both types of specifications (with and without outliers) in Table 11.

Performing the standard tests of suitability of the model (referring to specification OLS of Table 2), the Ramsey RESET test does not reject the null hypothesis, and thus the selected specification is not considered to be wrong. The results of multicollinearity analysis and analysis of non-linear relationships do not change when outliers are excluded. To deal with the possible presence of heteroskedasticity of disturbances, we use heteroskedasticity robust standard errors computed with the Huber-White sandwich estimator. To test for normality of disturbances, we employ the Shapiro-Wilk test, which rejects the null hypothesis. This is one of the reasons why we decided also to employ other methods, not only plain OLS like Görg and Strobl (2001).

The most obvious choice is to use some of the robust estimators, which can also help to assess whether the selected cut-off level for outliers in OLS was the right one. We decided for two alternative estimators: iteratively re-weighted least squares (IRLS) with Huber and Tukey bisquare weight functions tuned for 95\% Gaussian efficiency (see Hamilton, 2006, pp. 239-256) and median regression ${ }^{4}$ from the family of quantile regressions. The results of the robust meta-regression can be found in Table 12 in Appendix C. Concerning the selection of outliers in OLS, we can see that, for example, IRLS predicts results that are very similar to those of OLS without outliers. Therefore, we can conclude that the cut-off $\left|t_{k}\right| \leq 8$ does not seem to be improperly chosen.

Following Meyer and Sinani (2005), we also perform a random effects meta-regression. The cross-sectional dimension is represented by different papers; the other dimension is the order of the model taken from a particular paper. Because we have 97 observations from 67 papers at our disposal, it would not be practical to use the fixed-effects model, as many observations would be dropped and the number of degrees of freedom would diminish significantly, thus it is not even possible to test for fixed effects reliably. Therefore, we will assume that the study-specific effect is normally distributed. We will test the following unbalanced panel data model:

$$
Y_{i j}=\alpha_{i}+\sum_{l=1}^{L} \beta_{l} X_{i j l}+\varepsilon_{i j}, \quad i=1,2, \ldots, 67, \quad j=1,2, \ldots, 8
$$

Details of the random-effects meta-regression are reported in Table 13 in $\mathrm{Ap}$ pendix $C$. It is apparent that, excluding outliers, there is no substantial difference in the predictions of OLS and random-effects regression. Testing for random effects, the Breusch-Pagan Lagrange multiplier test does not reject the null hypothesis (it is significant only at the $15 \%$ level), thus it might suffice to perform plain OLS in this

\footnotetext{
${ }^{4}$ The algorithm minimizes the sum of the absolute deviations about the median.
} 
case. But there is one other advantage of the panel-data method: as Stanley (2001) remarks, if a meta-analyst takes a lot of observations from one paper, a single researcher (or even a single work) can dominate the whole meta-regression; panel-data methods might deliver more "balanced" results.

Another approach is to restrict the meta-response variable to a binary variable and employ the probit regression (for a related example, see Wooster and Diebel, 2006). Therefore, we construct a dummy variable which equals one when the $t$ statistic is positive, and zero otherwise. Moreover, we construct a similar dummy for significance: the dummy equals one if the absolute value of the $t$ statistic reaches the $5 \%$ critical value, and zero otherwise. Both models are estimated with normal probability regression and details can be found in Table 14 in Appendix C. Although there are slight differences between the results of the probit model when the response variable is the dummy for positiveness (specification 1 from Table 14) and our benchmark-case OLS, basically it tells the same story in terms of the significances and polarities of the estimates

When the dummy for significance is used as the meta-response variable, the only significant meta-explanatory variables are number of degrees of freedom in the study, average year of study period, and cross-sectionality of data. Our results suggest that a higher number of observations leads to more significant results (either positive or negative), which is what one would expect. Cross-sectional data bring more significant $t$-statistics. Moreover, the reported degree of significance seems to be declining over time - studies using newer data are more likely to find insignificant results.

The results of all the meta-regression methods are summarized in Table 2. We prefer random effects since this method accounts for dependencies within studies and between-study heterogeneity. The results of the other estimators are, nevertheless, not qualitatively different, which suggests that the results are robust to the particular methodology used. There are three meta-explanatory variables which are robustly significant at the 5\% level. Our results show that cross-sectional data, industry-level aggregation, and the use of share in employment as a proxy for foreign presence yields, in general, more positively significant outcomes than the other specifications. It does not seem to matter, on the other hand, how the response variable is defined.

The significance of the cross-sectionality of the original data set confirms the findings of Görg and Strobl (2001), who claim that the bias could be caused by time invariant variables which are not identified by the explanatory variables in cross-sectional spillover studies. Panel data methods can, on the other hand, uncover these effects, and thus are more reliable. Cross-sectional studies, especially in combination with industry-level data, can thus cause a causality problem - foreign investors may seek efficient and more productive industries for their investments, thus researchers would report a positive spillover effect, even if the particular industry had high productivity long before MNCs entered it. On the other hand, Proenca et al. (2006) argue that the classical panel data methods of spillover estimation may generate a downward bias and they recommend using the extended generalized method of moments.

Contrary to Görg and Strobl (2001), we also find the level of aggregation and the use of share in employment as a proxy for foreign presence significant. Concerning the former, industry-level aggregation over heterogeneous firms may generally 
lead to biased results (Görg and Greenaway, 2004), since it does not cope with firm-specific effects that can be correlated with foreign presence. Concerning the latter, employment-intensive foreign investments could generate larger spillovers through the labor turnover channel, contrary to sales-intensive foreign investors, who may, on the other hand, be more involved in the competition effect, which has ambiguous impacts on host-country firms (Meyer and Sinani, 2005). This could explain the significant coefficient that was obtained for the variable EMPL and might suggest that using the share of employment as a proxy for foreign presence is not a misspecification; however, the definition of the proxy for foreign presence deserves attention. Researchers should always check their outcomes on various definitions of proxies and try to explain possible different outcomes. ${ }^{5}$

It is also evident that the dominant specification of spillover testing has been changing over time. Since the first researchers followed the pioneering work of Caves (1974) and used cross-sectional data and industry-level aggregation, little had changed before Haddad and Harrison (1993) published their study on Morocco, where they - using firm-level panel data - found evidence of negative horizontal spillovers due to the competition effect. Nevertheless, not many researchers used panel data again till 1999, when the other highly influential work of Aitken and Harrison (1999) was published. Since then, panel-data and firm-level analysis has become more frequent and has been almost totally dominating the literature since 2003, leaving cross-sectional and industry-level methods mostly for countries where detailed data are not easily accessible, e.g., China. Because our results suggest that the (non)presence of a time dimension in the data is one of the crucial aspects of the study design, we decide to split the sample into two halves (studies published before 2003 and those published after), and employ the Chow test to check whether it was appropriate to pool the data in the first place. The Chow test is significant only at the $23 \%$ level, thus the data were probably pooled correctly. Still, it might be beneficial to estimate the model separately for the two time periods. ${ }^{6}$

The results of the meta-regressions for older studies are reported in Table 3. In the case of probit, the dummy for industry-level data had to be omitted since otherwise the probit model would not have converged. ${ }^{7}$ The Breusch-Pagan Lagrange multiplier test is significant at the $10 \%$ level and the random-effects model is preferred to plain OLS. Similarly as for the pooled sample of all studies, it seems to matter whether the data are cross-sectional, aggregated on the industry level, and whether the share of foreign presence is measured in employment. Contrary to the pooled sample, however, the fact whether data for transition countries are used and whether foreign presence is measured as share in output is also significant. In the older studies, firms in transition countries are more likely to benefit from horizontal FDI spillovers.

\footnotetext{
${ }^{5}$ There is a general problem connected with defining "foreign presence." As Castellani and Zanfei (2007) show, the common approach can cause downward bias in spillover estimates, since it assumes that changes of the same proportion in aggregate and foreign activities within an industry do not affect the response variable, whilst the contrary can be the case in reality.

${ }^{6}$ We also ran the Chow test for equality of regression coefficients for developing and other country subsamples, respectively. The null hypothesis was not rejected. When we estimated the model for both subsamples separately, the differences were not qualitatively important and thus are not reported.

${ }^{7}$ This does not mean, though, that INDUSTRY is insignificant. Conversely, it predicts a perfect fit - industry-level aggregation always yields positive $t$ statistics for spillovers in older studies.
} 
Table 3 Summary of Meta-Regressions, Old Studies

\begin{tabular}{|c|c|c|c|c|c|}
\hline $\begin{array}{l}\text { Response variable: } t \text { statistic; } \\
\text { dummy = } 1 \text { if positive (probit) }\end{array}$ & OLS & IRLS & $\begin{array}{l}\text { Median } \\
\text { reg. }\end{array}$ & RE & Probit \\
\hline \multirow[t]{2}{*}{ Logarithm of degrees of freedom } & 0.137 & 0.163 & $0.379^{*}$ & 0.137 & -0.121 \\
\hline & $(0.63)$ & $(0.76)$ & (1.82) & $(0.63)$ & $(-0.90)$ \\
\hline \multirow[t]{2}{*}{ Average year of study period } & 0.0265 & 0.0185 & -0.0291 & 0.0265 & -0.0285 \\
\hline & $(0.69)$ & $(0.42)$ & $(-0.63)$ & $(0.69)$ & $(-0.51)$ \\
\hline \multirow{2}{*}{$\begin{array}{l}\text { Dummy = } 1 \text { if data are } \\
\text { for developing country }\end{array}$} & 0.804 & 0.654 & -0.5470 & 0.804 & -0.0816 \\
\hline & $(1.00)$ & $(0.69)$ & $(-0.63)$ & (1.00) & $(-0.09)$ \\
\hline \multirow{2}{*}{$\begin{array}{l}\text { Dummy }=1 \text { if data are } \\
\text { for transition country }\end{array}$} & $3.018^{\star \star \star}$ & $2.931^{* \star}$ & $3.444^{\star \star \star}$ & $3.018^{* \star \star}$ & 0.984 \\
\hline & $(2.84)$ & $(2.60)$ & (3.49) & $(2.84)$ & (1.18) \\
\hline \multirow{2}{*}{$\begin{array}{l}\text { Dummy }=1 \text { if data are } \\
\text { cross-section }\end{array}$} & $1.382^{*}$ & 1.326 & $2.167^{\star \star}$ & $1.382^{*}$ & $1.810^{* * *}$ \\
\hline & (1.95) & $(1.42)$ & $(2.44)$ & (1.95) & (2.93) \\
\hline \multirow{2}{*}{$\begin{array}{l}\text { Dummy = } 1 \text { if response variable } \\
\text { is output growth }\end{array}$} & 0.527 & 0.434 & -0.0435 & 0.527 & -0.161 \\
\hline & $(0.93)$ & $(0.60)$ & $(-0.07)$ & $(0.93)$ & $(-0.27)$ \\
\hline \multirow{2}{*}{$\begin{array}{l}\text { Dummy = } 1 \text { if data are } \\
\text { industry-level }\end{array}$} & $3.057^{\star \star \star}$ & $3.168^{* *}$ & $3.580^{\star \star \star *}$ & $3.057^{\star \star \star}$ & \\
\hline & (3.29) & $(2.54)$ & (3.08) & (3.29) & \\
\hline \multirow{2}{*}{$\begin{array}{l}\text { Dummy = } 1 \text { if industry dummies } \\
\text { used }\end{array}$} & 0.191 & 0.506 & 0.787 & 0.191 & -0.763 \\
\hline & $(0.16)$ & $(0.47)$ & $(0.84)$ & $(0.16)$ & $(-0.93)$ \\
\hline \multirow{2}{*}{$\begin{array}{l}\text { Dummy = } 1 \text { if MNC presence } \\
\text { measured in employment }\end{array}$} & $2.397^{\star \star}$ & $2.308^{* \star}$ & $1.650^{*}$ & $2.397^{* *}$ & 0.701 \\
\hline & $(2.30)$ & $(2.04)$ & (1.71) & $(2.30)$ & $(0.80)$ \\
\hline \multirow{2}{*}{$\begin{array}{l}\text { Dummy }=1 \text { if } \mathrm{MNC} \text { presence } \\
\text { measured in assets }\end{array}$} & 0.225 & 0.288 & 0.0177 & 0.225 & 1.183 \\
\hline & $(0.21)$ & $(0.29)$ & $(0.02)$ & $(0.21)$ & $(1.60)$ \\
\hline \multirow{2}{*}{$\begin{array}{l}\text { Dummy = } 1 \text { if MNC presence } \\
\text { measured in output }\end{array}$} & $4.433^{\star \star \star}$ & $4.383^{* \star \star}$ & $4.559^{\star \star \star}$ & $4.433^{\star \star \star}$ & $1.718^{\star}$ \\
\hline & $(3.67)$ & $(3.46)$ & $(3.78)$ & $(3.67)$ & $(1.66)$ \\
\hline \multirow[t]{2}{*}{ Constant } & -57.65 & -41.82 & 51.75 & -57.65 & 56.18 \\
\hline & $(-0.75)$ & $(-0.48)$ & $(0.56)$ & $(-0.75)$ & $(0.51)$ \\
\hline Observations & 42 & 46 & 46 & 42 & 46 \\
\hline $\begin{array}{l}R^{2} \text { (pseudo } R^{2} \text { for } \\
\text { median reg. and probit) }\end{array}$ & 0.626 & 0.549 & 0.288 & 0.626 & 0.419 \\
\hline
\end{tabular}

Notes: OLS and RE computed excluding outliers; heteroskedasticity robust (Huber-White sandwich est.) $t$ sta-tistics in parenthesis.

${ }^{*} p<0.10,{ }^{* *} p<0.05,{ }^{* * *} p<0.01$

The results for newer studies can be found in Table 4. In the case of probit, one dummy (developing country) had to be dropped for the model to converge. The Breusch-Pagan test is not significant at any reasonable level, thus we put more weight on plain OLS. Estimated dependencies are much less apparent now than for the older studies. It is again important whether the data are cross-sectional and what the level of aggregation is, but no other meta-explanatory variable is significant in more than only one specification of Table 4. Thus, it appears that the pattern, still having basically the same shape, is getting weaker over time. This would suggest that, at least recently, researchers have been aware of this dependency of results on the study design and have begun to employ more balanced approaches, maybe even to compensate for the "expected" results. Indeed, the empirical literature has been diverging a lot since the work of Görg and Strobl (2001) was published. A significant number of new studies test for both intra-industry and inter-industry spillovers. The authors check multiple methodologies and compare the results. Nevertheless, there are still simple cross-sectional and/or industry-level studies, the results of which can mostly be predicted ex ante. 
Table 4 Summary of Meta-Regressions, New Studies

\begin{tabular}{|c|c|c|c|c|c|}
\hline $\begin{array}{l}\text { Response variable: } t \text { statistic; } \\
\text { dummy }=1 \text { if positive (probit) }\end{array}$ & OLS & IRLS & $\begin{array}{l}\text { Median } \\
\text { reg. }\end{array}$ & RE & Probit \\
\hline \multirow{2}{*}{$\begin{array}{l}\text { Logarithm of degrees } \\
\text { of freedom }\end{array}$} & 0.183 & 0.248 & 0.351 & 0.132 & -0.00712 \\
\hline & $(1.15)$ & $(1.20)$ & $(0.83)$ & $(0.79)$ & $(-0.06)$ \\
\hline \multirow[t]{2}{*}{ Average year of study period } & -0.150 & $-0.256^{\star *}$ & -0.277 & -0.119 & 0.0000351 \\
\hline & $(-1.26)$ & $(-2.17)$ & $(-0.92)$ & $(-1.07)$ & $(0.00)$ \\
\hline \multirow{2}{*}{$\begin{array}{l}\text { Dummy = } 1 \text { if data are } \\
\text { for developing country }\end{array}$} & -0.0703 & 0.900 & 1.874 & -0.356 & \\
\hline & $(-0.04)$ & $(0.61)$ & $(0.46)$ & $(-0.23)$ & \\
\hline \multirow{2}{*}{$\begin{array}{l}\text { Dummy }=1 \text { if data are } \\
\text { for transition country }\end{array}$} & 1.092 & 1.881 & 3.141 & 0.751 & 0.234 \\
\hline & $(0.56)$ & $(1.12)$ & $(0.69)$ & $(0.39)$ & $(0.37)$ \\
\hline \multirow{2}{*}{$\begin{array}{l}\text { Dummy }=1 \text { if data are } \\
\text { cross-section }\end{array}$} & $2.687^{\star *}$ & $3.213^{* \star}$ & 2.988 & $2.249^{* *}$ & 0.931 \\
\hline & $(2.72)$ & (2.68) & (1.07) & $(2.25)$ & $(1.04)$ \\
\hline \multirow{2}{*}{$\begin{array}{l}\text { Dummy = } 1 \text { if response variable } \\
\text { is output growth }\end{array}$} & 1.153 & $1.615^{*}$ & 1.187 & 0.818 & 0.160 \\
\hline & $(1.21)$ & $(1.77)$ & $(0.46)$ & $(0.91)$ & $(0.26)$ \\
\hline \multirow{2}{*}{$\begin{array}{l}\text { Dummy = } 1 \text { if data are } \\
\text { industry-level }\end{array}$} & $3.438^{\star \star}$ & $4.595^{\star \star \star}$ & 5.020 & $3.199^{\star *}$ & 0.656 \\
\hline & $(2.27)$ & (3.10) & $(1.37)$ & $(2.11)$ & $(0.66)$ \\
\hline \multirow{2}{*}{$\begin{array}{l}\text { Dummy = } 1 \text { if industry dummies } \\
\text { used }\end{array}$} & 0.936 & 1.579 & 2.856 & 1.002 & 0.675 \\
\hline & $(0.84)$ & $(1.60)$ & (1.05) & $(0.97)$ & $(1.15)$ \\
\hline \multirow{2}{*}{$\begin{array}{l}\text { Dummy = } 1 \text { if MNC presence } \\
\text { measured in employment }\end{array}$} & 2.046 & 2.299 & 3.765 & 2.108 & $2.283^{\star *}$ \\
\hline & (1.66) & (1.54) & $(0.87)$ & $(1.28)$ & $(2.50)$ \\
\hline \multirow{2}{*}{$\begin{array}{l}\text { Dummy }=1 \text { if } \mathrm{MNC} \text { presence } \\
\text { measured in assets }\end{array}$} & 0.651 & 1.118 & 1.537 & 0.757 & 1.400 \\
\hline & $(0.62)$ & $(0.79)$ & $(0.37)$ & $(0.49)$ & $(1.49)$ \\
\hline \multirow{2}{*}{$\begin{array}{l}\text { Dummy = } 1 \text { if MNC presence } \\
\text { measured in output }\end{array}$} & 0.396 & 1.057 & 0.768 & 0.687 & 0.794 \\
\hline & $(0.33)$ & $(0.79)$ & $(0.20)$ & $(0.39)$ & $(0.97)$ \\
\hline \multirow[t]{2}{*}{ Constant } & 295.9 & 503.2 & $544.2^{\star \star}$ & 234.6 & -1.516 \\
\hline & $(1.26)$ & $(2.16)$ & $(0.91)$ & $(1.07)$ & $(-0.01)$ \\
\hline Observations & 45 & 51 & 51 & 45 & 51 \\
\hline $\begin{array}{l}R^{2} \text { (pseudo } R^{2} \text { for median reg. } \\
\text { and probit) }\end{array}$ & 0.314 & 0.348 & 0.099 & 0.302 & 0.208 \\
\hline
\end{tabular}

Notes: OLS and RE computed excluding outliers; heteroskedasticity robust (Huber-White sandwich est.) $t$ sta-tistics in parenthesis.

${ }^{*} p<0.10,{ }^{* *} p<0.05,{ }^{* * *} p<0.01$

\section{Publication Bias}

Stanley (2001) highlights the "file drawer" problem that occurs when researchers tend to publish only or mostly studies that are able to demonstrate significant results or that are consistent with the predominant theory because these are more likely to be accepted for publication in academic journals. It has been shown, e.g., by Card and Krueger (1995) that the "file drawer" problem can be extremely significant in economic publishing. Specifically, for the literature on minimum wages and employment they find vast evidence of publication bias. The same phenomenon was detected by Görg and Strobl (2001) in the spillover literature and both subsequent meta-analyses - Meyer and Sinani (2005) and Wooster and Diebel (2006) report similar results using the same methodology.

First, we employ the test advocated by Card and Krueger (1995) and applied by Görg and Strobl (2001) to the spillover literature. The set-up is illustrated in (5) we regress the absolute value of the $t$ statistics reported by the $k$-th model on the natural logarithm of the square root of the number of degrees of freedom in the $k$-th 
Table 5 Test of Publication Bias, OLS

\begin{tabular}{lcccc}
\hline Response variable: absolute value & & & & \\
of $t$ statistic & $(1)$ & $(2)$ & $(3)$ & $(4)$ \\
\hline Logarithm of square root of degrees & $1.165^{* *+*}$ & $1.161^{*+*}$ & $0.865^{*+}$ & $1.163^{*+*}$ \\
of freedom & $(2.95)$ & $(2.71)$ & $(2.33)$ & $(2.70)$ \\
Average year of study period & -0.0235 & -0.0168 & & \\
& $(-0.59)$ & $(-0.46)$ & & \\
Dummy $=1$ if data are & -0.564 & -0.600 & & \\
for developing country & $(-0.31)$ & $(-0.43)$ & & -0.463 \\
Dummy $=1$ if data are & -0.976 & -0.196 & & $(-0.27)$ \\
for transition country & $(-0.38)$ & $(-0.14)$ & & $3.403^{* *}$ \\
Dummy $=1$ if data are cross-section & $3.419^{*}$ & 2.605 & & $(2.07)$ \\
& $(1.98)$ & $(1.63)$ & & 1.684 \\
Dummy $=1$ if response variable is & 1.620 & & 1.220 & $(1.50)$ \\
output growth & $(1.26)$ & & $(0.96)$ & -0.670 \\
Dummy $=1$ if data are industry-level & -0.515 & & 0.597 & $(-0.57)$ \\
& $(-0.42)$ & & $(0.67)$ & \\
Dummy $=1$ if industry dummies used & 0.559 & & -0.534 & \\
& $(0.58)$ & & $(-0.39)$ & \\
Dummy $=1$ if MNC presence & -0.809 & & 0.0417 & -0.498 \\
measured in employment & $(-0.29)$ & & $(0.02)$ & $(-0.28)$ \\
Dummy $=1$ if MNC presence & 0.0104 & & 0.388 & \\
measured in assets & $(0.01)$ & & $(0.21)$ & \\
Dummy $=1$ if MNC presence & -1.532 & & -0.428 & -1.415 \\
measured in output & $(-0.90)$ & & $(-0.28)$ & $(-1.14)$ \\
Constant & 45.06 & 31.81 & -0.517 & -2.177 \\
& $(0.56)$ & $(0.44)$ & $(-0.31)$ & $(-1.09)$ \\
\hline Observations & 97 & 97 & 97 & 97 \\
$R^{2}$ & 0.127 & 0.083 & 0.050 & 0.123 \\
$t\left(H_{0}: \beta=1\right.$ ) & 0.170 & 0.140 & 0.130 & 0.140 \\
\hline
\end{tabular}

Notes: Heteroskedasticity robust (Huber-White sandwich est.) $t$ statistics in parenthesis.

${ }^{*} p<0.10,{ }^{* *} p<0.05,{ }^{* * *} p<0.01$

model, controlling also for all other meta-explanatory variables which were included in model (3):

$$
\left|t_{k}\right|=\alpha+\beta \log \left(\sqrt{M_{k}}\right)+\sum_{l=1}^{L-1} \gamma_{l} X_{k l}+\varepsilon_{k}, \quad k=1,2, \ldots, K
$$

where $M_{k}$ is the number of degrees of freedom in the $k$-th model. The crucial point of this test is the (non)significance and magnitude of the estimated parameter $\beta$. Under the null hypothesis of no publication bias, it should hold that $\beta=1$. In other words, the logarithm of the square root of degrees of freedom should increase the final model's $t$ statistic for foreign presence proportionally angle-wise 45 degrees.

The results of the publication bias test are reported in Table 5. It is a good sign that, under any specification, the estimate of $\beta$ is significant at least at the $5 \%$ level and it is positive, which suggests that more degrees of freedom, ceteris paribus, increase the results' level of significance, as should be the case with unbiased literature. The estimated values of $\beta$ are very close to 1 for all specifications. Testing the hypothesis $\beta=1$ with a simple $t$ test, we conclude that there is no sign of pub- 


\section{Figure 1 Funnel Plot}

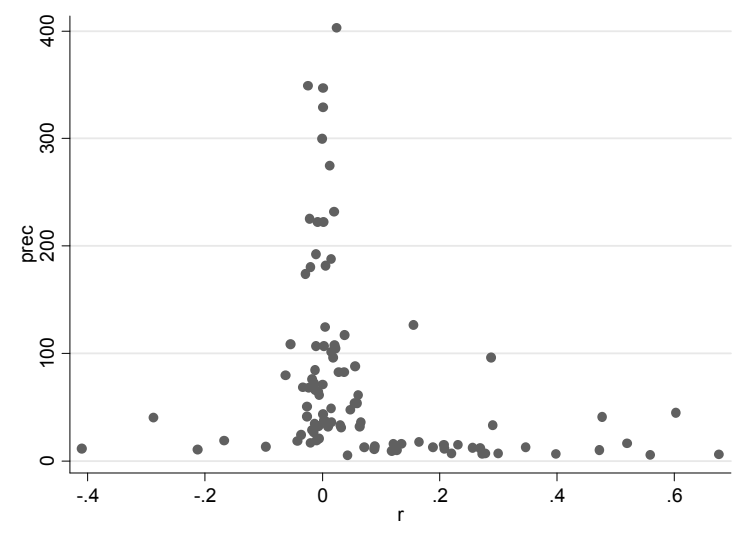

lication bias using this methodology (the corresponding test statistics are available in Table 5 as well).

However, the presented test for publication bias, employed by all previous meta-analyses of the spillover effect, was criticized by Doucouliagos and Stanley (2009). They show that the methodology of Card and Krueger (1995) in fact confuses publication bias with testing for the underlying "true effect." An alternative way to test for publication bias is to transform the $t$ statistics to partial correlation coefficients following Doucouliagos and Laroche (2009) and compute the corresponding standard errors. This conversion is necessary; regression coefficients cannot be used because they are not directly comparable. Partial correlation coefficients, similar to the simple correlation coefficients, show the statistical strength of the relationship between two variables - in this case, domestic firms' productivity and foreign presence in the sector. Now the most precise estimates of the underlying effect should lie close to the "true" partial correlation coefficient, and the estimates with lower precision should be more dispersed around this value. A natural measure of precision is the inverse of the standard error; $1 / \mathrm{se}$. In the absence of publication bias, plotting precision against partial correlation coefficients should thus yield a symmetric inverted funnel (Stanley and Doucouliagos, 2010a).

The literature on horizontal FDI spillovers produces Figure 1. The funnel is not entirely symmetric; the positive part is evidently heavier, suggesting that negative estimates have a lower chance of being published. Compared to other areas of empirical economic research, however, the publication bias is moderate (see Doucouliagos and Stanley, 2008). It is apparent that the estimates with the highest precision are concentrated very close to zero, which suggests that the underlying effect beyond publication bias may be very small. Some researchers even argue that it might paradoxically be efficient to discard $90 \%$ of the data and draw inferences only from the $10 \%$ remaining observations with the highest precision (Stanley and Doucouliagos, 2010b). Since the funnel has only a single peak, we can also see that our sample is relatively homogeneous. It is the nature of such visual tests, however, that they can be interpreted subjectively. Fortunately, a simple formalization of the "funnel asymmetry test" exists. It allows us to test the presence and magnitude of publication bias and the underlying effect of foreign presence on domestic firms' productivity. 
Table 6 Alternative Test of Publication Bias

\begin{tabular}{lccc}
\hline Response variable: $t$ statistic & OLS & IRLS & RE \\
\hline True effect (1/se) & -0.00328 & $-0.00654^{* \star}$ & -0.00189 \\
& $(-0.51)$ & $(-2.15)$ & $(-0.29)$ \\
Publication bias (constant) & $1.904^{\star \star \star}$ & $1.234^{* \star *}$ & $1.822^{* \star *}$ \\
& $(2.83)$ & $(3.50)$ & $(2.63)$ \\
\hline Observations & 97 & 97 & 97 \\
\hline
\end{tabular}

Notes: Heteroskedasticity robust $t$ statistics in parenthesis.

${ }^{*} p<0.10,{ }^{* *} p<0.05,{ }^{* * *} p<0.01$

In the absence of publication bias, the estimates should be randomly distributed around the true value $(\beta)$ with no dependence on the standard error $\left[\beta_{1}\right.$ in $(6)$ should be zero]:

$$
r_{k}=\beta+\beta_{1} s e_{k}+\varepsilon_{k}
$$

where $r$ denotes the partial correlation coefficient estimated in the literature, se the corresponding standard error, and $\varepsilon$ the normal disturbance term. Because specification (6) is obviously heteroskedastic, the weighted least squares version is usually employed:

$$
r_{k} / s e_{k}=t_{k}=\beta / s e_{k}+\beta_{1}+\varphi_{k}
$$

Specification (7) can also be derived directly from the funnel plot by switching the axes and dividing the partial correlation coefficients by the standard errors to remove heteroskedasticity.

The results of the funnel asymmetry test are reported in Table 6. Following Krassoi-Peach and Stanley (2009) and Doucouliagos and Stanley (2009), we use standard OLS as a benchmark and additionally employ robust and random effects versions of the regression (the random effects panel estimator accounts for heterogeneity between studies). All estimators yield similar results. The constant term is significant, which suggests that publication bias is present in the spillover literature; its intensity (we obtain values from 1.2 to 1.9) can be classified as moderate following Stanley and Doucouliagos (2010a). ${ }^{8}$ While the majority of applied economics shows more severe publication selection bias, the results contradict those of the traditional test for publication bias introduced by Card and Krueger (1995) and first applied to the spillover literature by Görg and Strobl (2001). The new methodology allows us to estimate the "true" effect net of publication bias [ $\beta$ from (6)], which is also presented in Table 6. The true effect is (negatively) significant only in one specification - and even in this case it is very small and probably of little practical importance. We thus present evidence that the average reported spillover effect, which is strongly positive (see Section 4), arises largely due to publication bias.

\section{Conclusion}

This paper presents a meta-analysis of the empirical literature on horizontal productivity spillovers from FDI. We gather a sample of 97 models from 67 studies published either in academic journals or as working papers. Using the vote-counting

\footnotetext{
${ }^{8}$ Publication bias is not significant at the 5\% level if only studies published after 2003 are included in the regression.
} 
method, the spillover effect is not significant in general; employing the approach of Djankov and Murrell (2002), on the other hand, there is some evidence that positive spillovers from FDI might exist. Nevertheless, this is not the case with the narrower sample of studies that were published in the best economics journals or that use panel and firm-level data (and thus are more reliable). Once publication selection bias is accounted for, the aggregated effect is insignificant, no matter what methodology is used. Therefore, we argue that there is no general persuasive empirical evidence on intra-industry spillovers.

We further investigate which study aspects affect the reported significance and polarity of spillovers using a meta-regression analysis which was elaborated by Stanley and Jarrell (1989). Subject to several sensitivity checks, we find that the study results are predictably affected by the study design, namely, by the use of cross-sectional or panel data, industry- or firm-level aggregation, and specification of the proxy of foreign presence in the industry. Our results suggest that cross-sectional studies tend to report excessively high spillovers, as do models with industry-level aggregation and employment as a proxy for foreign presence. However, this pattern appears to become weaker over time, suggesting that newer studies may suffer less from such bias.

Following Card and Krueger (1995), we test for publication bias in the spillover literature. Contrary to Görg and Strobl (2001), we do not find evidence of publication bias employing this methodology. When the preferred funnel asymmetry test (Doucouliagos and Stanley, 2009; Doucouliagos and Laroche, 2009) is used, however, moderate publication bias is identified in the literature.

Economic and business researchers all over the world have devoted many man-hours to investigating horizontal spillovers from foreign direct investment. Is it "much ado about nothing" as Görg and Greenaway (2004) suggest in the title of their article? While the spillover effect is probably heterogeneous across different countries and industries, the worrying issue is that the results are systematically dependent on the methodology chosen. In other words, the researcher can influence her results ex ante by simply choosing a particular methodology. A strong consensus has formed in the international research community that firm-level panel data are the appropriate tool for testing for the presence of spillovers from foreign direct investment. For many countries, however, such detailed data are often difficult to construct, and cross-sectional studies are still being published. The outcome of such studies is predictable to a large extent. The pattern, however, does not concern only the nature of the data. Contrary to Görg and Strobl (2001), our meta-regression analysis shows that the definition of the proxy for foreign presence is important as well and can also yield predictable results. Unfortunately, many studies do not report sensitivity analysis with respect to the definition of foreign presence. When they do, as for instance in Geršl (2008), they often find that the spillover effect is not robust. Such pattern of predictability is widespread in economic research. Indeed, Stanley (2001) shows how one of his older meta-regression analyses on the union wage premium (Jarrell and Stanley, 1990), coincidentally published in the same issue as a new empirical study on the topic, precisely estimated the results of that study once its characteristics were plugged into the meta-regression. It is natural that heterogeneous research brings heterogeneous results. Researchers should, however, be aware of the predictability pattern, best identified by meta-regression analyses, and report as much thorough sensitivity analysis as possible. 
The other problematic issue of the spillover literature is publication bias. While the identified magnitude of the bias is not extreme, it is high enough to produce statistically significant results on average where there are probably none in reality. In a meta-meta analysis (meta-regression analysis of meta-analyses), Doucouliagos and Stanley (2008) show that theory competition is crucial for the resulting empirical publication bias in a particular field. For example, the neoclassical theory predicts the effect of raising the minimum wage on employment to be negative. Doucouliagos and Stanley (2009) illustrate how it is harder for positive estimates to be published, which causes the simple average taken from the literature to be biased toward negative values. Thus, in this respect, it is beneficial for each empirical field to have a competitive theoretical background. Concerning the spillover literature, theory competition has increased considerably during the last two decades. Negative results have become accepted without much ado. It is thus possible that publication bias will become less problematic in the coming years. Indeed, a funnel asymmetry test executed on the subsample of new studies is not significant at the 5\% level, indicating no formal evidence for publication selection among such studies.

Future research should focus on inter-industry spillovers, since they seem to be more promising. The number of empirical studies in this field is growing and will soon be sufficient for a meta-regression analysis. Intra-industry productivity spillovers, on the other hand, appear to stay nonexistent or undetectable after correcting for publication bias.

\section{REFERENCES}

Aitken BJ, Harrison AE (1999): Do Domestic Firms Benefit from Direct Foreign Investment? Evidence from Venezuela. American Economic Review, 89(3):605-618.

Aslanoglu E (2000): Spillovers effect of foreign direct investment on Turkish manufacturing industry. Journal of International Development, 12:1111-1130.

Audretsch DB (1998): Agglomeration and the Location of Innovative Activity. Oxford Review of Economic Policy, 14(2):18-29.

Barrios S (2000): Foreign Direct Investment Productivity Spillovers. Evidence from the Spanish Experience (1990-1994). FEDEA, Working Papers, no. 2000-19 (Madrid).

Barrios S, Dimelis S, Louri H, Strobl E (2002): Efficiency Spillovers from Foreign Direct Investment in the EU Periphery: A Comparative Study of Greece, Ireland and Spain. FEDEA, Working Papers, no. 2002-02 (Madrid).

Barrios S, Strobl E (2002): Foreign direct investment and productivity spillovers: Evidence from the Spanish experience. Review of World Economics, 138(3):459-481.

Blalock G, Gertler PJ (2005): Welfare Gains from Foreign Direct Investment through Technology Transfer to Local Suppliers. Working paper, University of California (Berkeley).

Blomström M (1986): Foreign Investment and Productive Efficiency: The Case of Mexico. Journal of Industrial Economics, 35(1):97-110.

Blomström M, Kokko A (1996): Multinational Corporations and Spillovers. CEPR (Center for Economic Policy Research) Discussion Papers, no. 1365.

Blomström M, Kokko A (2003): The Economics of Foreign Direct Investment Incentives. NBER (National Bureau of Economic Research, Inc.) Working Papers, no. 9489.

Blomström M, Kokko A, Zejan M (1994): Host country competition, labor skills, and technology transfer by multinationals. Review of World Economics, 130(3):521-533. 
Blomström M, Persson H (1983): Foreign investment and spillover efficiency in an underdevel-oped economy: Evidence from the Mexican manufacturing industry. World Development, 11(6):493-501.

Blomström M, Sjöholm F (1999): Technology transfer and spillovers: Does local participation with multinationals matter? European Economic Review, 43(4-6):915-923.

Blomström M, Wolff EN (1994): Multinational Corporations and Productivity Convergence in Mexico. In: Baumol WJ, Nelson RR, Wolff EN (Eds.): Convergence of Productivity: Cross National Studies and Historical Evidence. Oxford University Press, pp. 263-283.

Bosco MG (2001): Does FDI contribute to technological spillovers and growth? A panel data analysis of Hungarian firms. Transnational Corporations, 10(1):43-67.

Bouoiyour J (2003): Labour Productivity, Technological Gap and Spillovers: Evidence from Moroccan Manufacturing Industries. WPCATT, Working papers, University of Pau.

Buckley PJ, Wang C, Clegg J (2002): The impact of inward FDI on the performance of Chinese manufacturing firms. Journal of International Business Studies, 33(4):637-655.

Buckley PJ, Wang C, Clegg J (2007): The impact of foreign ownership, local ownership and industry characteristics on spillover benefits from foreign direct investment in China. International Business Review, 16(2):142-158.

Bwalya SM (2006): Foreign direct investment and technology spillovers: Evidence from panel data analysis of manufacturing firms in Zambia. Journal of Development Economics, 81(2):514-526.

Card D, Krueger AB (1995): Time-Series Minimum-Wage Studies: A Meta-analysis. American Economic Review, 85(2):238-43.

Castellani D, Zanfei A (2007): Multinational companies and productivity spillovers: is there a specification error? Applied Economics Letters, 14(14):1047-1051.

Caves RE (1974): Multinational Firms, Competition, and Productivity in Host-Country Markets. Economica, 41(162):176-93.

Chuang Y, Lin C (1999): Foreign direct investment, R\&D and spillover efficiency: evidence from Taiwan's manufacturing firms. Journal of Development Studies, 35:117-137.

Corden WM (1974): Trade Policy and Economic Welfare. Oxford University Press, London.

Crespo N, Fontoura MP (2007): Determinant Factors of FDI Spillovers - What Do We Really Know? World Development, 35(3):410-425.

Damijan JP, Majcen B, Rojec M, Knell M (2001): The role of FDI, R\&D accumulation, and trade in transferring technology to transmission countries: evidence from firm panel data for eight transition countries. University of Ljubljana, Institute for Economic Research, Working Papers, no. 2001/10.

Djankov S, Hoekman BM (2000): Foreign Investment and Productivity Growth in Czech Enterprises. World Bank Economic Review, 14(1):49-64.

Djankov S, Murrell P (2002): Enterprise Restructuring in Transition: A Quantitative Survey. Journal of Economic Literature, 40(3):739-792.

Doucouliagos H, Laroche P (2009): Unions and Profits: A Meta-Regression Analysis. Industrial Relations, 48(1):146-184.

Doucouliagos H, Stanley T (2008): Theory Competition and Selectivity: Are All Economic Facts Greatly Exaggerated? Deakin University, Faculty of Business and Law, School of Accounting, Economics and Finance, Economics Series, no. 06.

Doucouliagos H, Stanley TD (2009): Publication Selection Bias in Minimum-Wage Research? A Meta-Regression Analysis. British Journal of Industrial Relations, 47(2):406-428.

Driffield N (2001): The Impact of Domestic Productivity of Inward Investment in the UK. Manchester School, 69(1):103-19.

Fidrmuc J, Korhonen I (2006): Meta-analysis of the business cycle correlation between the euro area and the CEECs. Journal of Comparative Economics, 34(3):518-537. 
Flores RG, Fontoura MP, Santos RG (2000): Foreign direct investment spillovers: what can we learn from Portuguese data? Graduate School of Economics, Getulio Vargas Foundation (Brazil), Economics Working Papers (Ensaios Economicos da EPGE), no. 4/2000.

Fosfuri A, Motta M, Ronde T (2001): Foreign direct investment and spillovers through workers' mobility. Journal of International Economics, 53(1):205-222.

Gallet C (2007): A Comparative Analysis of the Demand for Higher Education: Results from a Meta-analysis of Elasticities. Economics Bulletin, 9(7):1-14.

Geršl A (2008): Productivity, Export Performance, and Financing of the Czech Corporate Sector: The Effects of Foreign Direct Investment. Finance a úvěr-Czech Journal of Economics and Finance, 58:232-247.

Girma S (2003): Absorptive capacity and productivity spillovers from FDI: A threshold regression analysis. European Economy Group, Working paper series , no. 25.

Girma S, Greenaway D, Wakelin K (2001): Who Benefits from Foreign Direct Investment in the UK? Scottish Journal of Political Economy, 48(2):119-33.

Girma S, Wakelin K (2007): Local productivity spillovers from foreign direct investment in the U.K. electronics industry. Regional Science and Urban Economics, 37:399-412.

Globerman S (1979): Foreign Direct Investment and 'Spillover' Efficiency Benefits in Canadian Manufacturing Industries. Canadian Journal of Economics, 12(1):42-56.

Görg H, Greenaway D (2004): Much Ado about Nothing? Do Domestic Firms Really Benefit from Foreign Direct Investment? World Bank Research Observer, 19(2):171-197.

Görg H, Strobl E (2001): Multinational Companies and Productivity Spillovers: A Meta-analysis. Economic Journal, 111(475):F723-39.

Görg H, Strobl E (2004): Foreign direct investment and local economic development: Beyond productivity spillovers. The University of Nottingham, GEP Research Paper, no. 2004/11.

Griffith R, Redding S, Reenen JV (2003): R\&D and Absorptive Capacity: Theory and Empirical Evidence. Scandinavian Journal of Economics, 105(1):99-118.

Haddad M, Harrison A (1993): Are there positive spillovers from direct foreign investment? Evidence from panel data for Morocco. Journal of Development Economics, 42(1):51-74.

Hamilton LC (2006): Statistics with STATA. Duxbury Press.

Haskel JE, Pereira SC, Slaughter MJ (2004): Does Inward Foreign Direct Investment Boost the Productivity of Domestic Firms? Tuck School of Business at Darmouth, Working paper series.

Havránek T (2010): Rose Effect and the euro: Is the magic gone? Review of World Economics, (forthcoming). DOI: 10.1007/s10290-010-0050-1.

Hedges LV, Olkin I (1985): Statistical Methods of Meta-Analysis. Academic Press, Orlando.

Hermes N, Lensink R (2003): Foreign direct investment, financial development and economic growth. The Journal of Development Studies, 40(1):142-163.

Hunter J, Schmidt F (1990): Methods of Meta-analysis: Correcting Error and Bias in Research Findings. 1st edition. Sage Publications, Newbury Park (CA).

Imbriani C, Reganati F (1999): Productivity spillovers and regional differences: some evidence on the Italian manufacturing sector. Universita degli Studi di Salerno, Discussion Paper Series, no. 48.

Jarrell SB, Stanley TD (1990): A meta-analysis of the union-nonunion wage gap. Industrial and Labor Relations Review, 44(1):54-67.

Javorcik BS (2004): Does Foreign Direct Investment Increase the Productivity of Domestic Firms? In: Search of Spillovers through Backward Linkages. American Economic Review, 94(3):605-627.

Javorcik BS, Spatareanu M (2008): To share or not to share: Does local participation matter for spillovers from foreign direct investment? Journal of Development Economics, 85(1-2):194-217.

Jordaan JA (2005): Determinants of FDI-induced externalities: New empirical evidence for Mexican manufacturing industries. World Development, 33(12):2103-2118. 
Kalaitzidakis P, Mamuneas TP, Stengos T (2003): Rankings of Academic Journals and Institutions in Economics. Journal of the European Economic Association, 1(6):1346-1366.

Kathuria V (2000): Productivity spillovers from technology transfer to Indian manufacturing firms. Journal of International Development, 12:343-369.

Kathuria V (2002): Liberalisation, FDI, and productivity spillovers - an analysis of Indian manufacturing firms. Oxford Economic Papers, 54(4):688-718.

Keller W, Yeaple SR (2003): Multinational Enterprises, International Trade, and Productivity Growth: Firm-Level Evidence from the United States. NBER Working Papers, no. 9504.

Khawar M (2003): Productivity and foreign direct investment - evidence from Mexico. Journal of Economic Studies, 30(1):66-76.

Kinoshita Y (2000): R\&D and Technology Spillovers via FDI: Innovation and Absorptive Capacity. William Davidson Institute at the University of Michigan, Working Papers Series, no. 349.

Kohpaiboon A (2006): Foreign direct investment and technology spillover: A cross-industry analysis

of Thai manufacturing. World Development, 34(3):541-556.

Kokko A (1994): Technology, market characteristics, and spillovers. Journal of Development Econo-mics, 43(2):279-293.

Kokko A (1996): Productivity spillovers from competition between local firms and foreign affiliates. Journal of International Development, 8:517-530.

Kokko A, Blomström M (1995): Policies to encourage inflows of technology through foreign multinationals. World Development, 23(3):459-468.

Kokko A, Zejan M, Tansini R (1996): Local technological capability and productivity spillovers from FDI in the Uruguayan manufacturing sector. Journal of Development Studies, 32:602-611.

Kokko A, Zejan M, Tansini R (2001): Trade regimes and spillover effects of FDI: Evidence from Uruguay. Review of World Economics, 137(1):124-149.

Konings J (2000): The Effect of Direct Foreign Investment on Domestic Firms: Evidence from Firm Level Panel Data in Emerging Economies. William Davidson Institute, Working Paper Series, no. 344 .

Krassoi-Peach E, Stanley T (2009): Efficiency Wages, Productivity and Simultaneity: A Meta-Regression Analysis. Journal of Labor Research, 30(3):262-268.

Lee JY, Mansfield E (1996): Intellectual Property Protection and U.S. Foreign Direct Investment. The Review of Economics and Statistics, 78(2):181-86.

Li H, Grijalva T, Berrens RP (2007): Economic growth and environmental quality: a meta-analysis of environmental Kuznets curve studies. Economics Bulletin, 17(5):1-11.

Lipsey R, Sjöholm F (2004): FDI and wage spillovers in Indonesian manufacturing. Review of World Economics, 140(2):321-332.

Liu X, Parker D, Vaiyda K, Wei Y (2001): The impact of foreign direct investment on labour productivity in the Chinese electronics industry. International Business Review, 10:421-439.

Liu X, Siler P, Wang C, Wei Y (2000): Productivity Spillovers from Foreign Direct Investment: Evidence from UK Industry Level Panel Data. Journal of International Business Studies, 31(3): 407-425.

Liu X, Wang C (2003): Does foreign direct investment facilitate technological progress? Evidence from Chinese industries. Research Policy, 32(6):945-953.

Liu Z (2002): Foreign Direct Investment and Technology Spillover: Evidence from China. Journal of Comparative Economics, 30(3):579-602.

Liu Z (2008): Foreign direct investment and technology spillovers: Theory and evidence. Journal of Development Economics, 85(1-2):176-193. 
Lutz S, Talavera O (2004): Do Ukrainian Firms Benefit from FDI? Economics of Planning, 37(2): 77-98.

MacDougall GDA (1960): The Benefits and Costs of Private Investment from Abroad: A Theoretical Approach. Economic Record, 36:13-35.

Marin A, Bell M (2004): Technology spillovers from foreign direct investment: the active role of MNC subsidiaries in Argentina in the 1990s. Science and Technology Policy Research (UK), SPRU Electronic Working Paper Series, no. 118.

Merlevede B, Schoors K (2006): FDI and the Consequences Towards more complete capture of spillover effects. Ghent University, Faculty of Economics and Business Administration, Working Papers, no. 06/372.

Meyer KE, Sinani E (2005): Spillovers from Foreign Direct Investment: A Meta Analysis. Copenhagen Business School, Center for East European Studies, Working Paper Series, no. 59.

Murakami Y (2007): Technology spillover from foreign-owned firms in Japanese manufacturing industry. Journal of Asian Economics, 18(2):284-293.

Narula R, Marin A (2005): Exploring the relationship between direct and indirect spillovers from FDI in Argentina. Maastricht Economic Research Institute on Innovation and Technology, Research Memoranda, no. 024.

Nguyen PL (2008): Productivity Spillovers from Foreign Direct Investment: Evidence from Vietnamese Firm Data. University of South Australia, School of Commerce, Working paper series.

Pack H, Saggi K (1997): Inflows of Foreign Technology and Indigenous Technological Development. Review of Development Economics, 1(1):81-98.

Peri G, Urban D (2006): Catching-up to foreign technology? Evidence on the "Veblen-Gerschenkron" effect of foreign investments. Regional Science and Urban Economics, 36(1):72-98.

Proença I, Fontoura P, Crespo N (2006): Productivity Spillovers from Multinational Corporations in Portugal: Vulnerability to Deficient Estimation. Applied Econometrics and International Development, 6(1):87-98.

Ran J, Voon JP, Li G (2007): How does FDI affect China? Evidence from industries and provinces. Journal of Comparative Economics, 35(4):774-799.

Rattsoe J, Stokke HE (2003): Learning and foreign technology spillovers in Thailand: Empirical evidence on productivity dynamics. Norwegian University of Science and Technology, Department of Economics, Working paper series.

Ruane F, Ugur A (2003): Foreign direct investment and productivity spillovers in Irish manufacturing industry: evidence from plant level panel data. Trinity College Dublin, Department of Economics, Working paper series.

Sadik AT, Bolbol AA (2001): Capital Flows, FDI, and Technology Spillovers: Evidence from Arab Countries. World Development, 29(12):2111-2125.

Sasidharan S, Ramanathan A (2007): Foreign Direct Investment and spillovers: evidence from Indian manufacturing. The International Journal of Trade and Global Markets, 1(1):5-22.

Schoors K, Tol BVD (2002): Foreign direct investment spillovers within and between sectors: Evidence from Hungarian data. Ghent University, Faculty of Economics and Business Administration, Working Papers, no. 02/157.

Sgard J (2001): Direct Foreign Investments and Productivity Growth in Hungarian Firms, 1992 -1999. William Davidson Institute at the University of Michigan, Working Papers Series, no. 425.

Sinani E, Meyer KE (2004): Spillovers of technology transfer from FDI: the case of Estonia. Journal of Comparative Economics, 32(3):445-466.

Sjöholm F (1999a): Productivity Growth in Indonesia: The Role of Regional Characteristics and Direct Foreign Investment. Economic Development and Cultural Change, 47(3):559-84.

Sjöholm F (1999b): Technology Gap, Competition and Spillovers from Direct Foreign Investment: Evidence from Establishment Data. Journal of Development Studies, 36:53-73. 
Stanley T, Doucouliagos H (2010a): A simple graph that reveals much ado about research. Journal of Economic Surveys, 24(1):170-191.

Stanley T, Doucouliagos H (2010b): Could it be better to discard $90 \%$ of the data? A statistical paradox. The American Statistician, 64(1):70-77.

Stanley TD (2001): Wheat from Chaff: Meta-analysis as Quantitative Literature Review. Journal of Economic Perspectives, 15(3):131-150.

Stanley TD, Jarrell SB (1989): Meta-Regression Analysis: A Quantitative Method of Literature Surveys. Journal of Economic Surveys, 3(2):161-70.

Takii S (2005): Productivity spillovers and characteristics of foreign multinational plants in Indonesian manufacturing 1990-1995. Journal of Development Economics, 76(2):521-542.

Thuy LT (2005): Technological Spillovers from Foreign Direct Investment: the case of Vietnam. University of Tokio, Graduate School of Economics, Working paper.

Torlak E (2004): Foreign Direct Investment, Technology Transfer and Productivity Growth in Transition Countries: Empirical Evidence from Panel Data. University of Goettingen, CEGE (Center for European, Governance and Economic Development Research), Discussion Papers, no. 26.

Vahter P (2004): The Effect of Foreign Direct Investment on Labour Productivity: Evidence from Estonia and Slovenia. University of Tartu, Faculty of Economics and Business Administration, Working Paper Series, no. 32.

Víšek JA (1997): Ekonometrie I. Charles University, Prague.

Wang JY, Blomstrom M (1992): Foreign investment and technology transfer: A simple model. European Economic Review, 36(1):137-155.

Wei Y, Liu X (2003): Productivity spillovers among OECD, diaspora and indigenous firms in Chinese manufacturing. Lancaster University Management School, Economics Department, Working Papers, no. 2003/008

Wooster RB, Diebel DS (2006): Productivity Spillovers from Foreign Direct Investment in Developing Countries: A Meta-Regression Analysis. Working paper, Available at SSRN:

http://ssrn.com/abstract $=898400$.

Xu B (2000): Multinational enterprises, technology diffusion, and host country productivity growth. Journal of Development Economics, 62(2):477-493.

Yudaeva K, Konstantin K, Melentieva N, Ponomareva N (2000): Does Foreign Ownership Matter? Russian Experience. Center for Economic and Financial Research (CEFIR), Working Papers, no. 5.

Zemplinerová A, Jarolím M (2001): Modes of FDI Entry and Firm Performance in Transition: The Czech Case. Transnational Corporations, 10:95-111.

Zhu G, Tan KY (2000): Foreign direct investment and labor productivity: New evidence from China as the Host. Thunderbird International Business Review, 42(5):507-528. 